\title{
Development of sorghum-wheat composite bread and evaluation of nutritional, physical and sensory acceptability
}

\author{
${ }^{1}$ Mariera Lucy., ${ }^{2}$ Owuoche James O., ${ }^{1 *}$ Cheserek Maureen \\ ${ }^{1}$ Department of Human Nutrition, Egerton University P.O Box 536 Egerton, Kenya. \\ ${ }^{2}$ Department of crops, Horticulture and Soil Science, Egerton University P.O Box 536 Egerton,Kenya. \\ . ${ }^{*}$ Corresponding Author's E-mail:mjcheserek@yahoo.co.uk/mcheserek@egerton.ac.ke.com, +254-0701-885509
}

\section{ABSTRACT}

\begin{abstract}
Increase in bread consumption, health awareness and demand for nutritious foods has necessitated research on composite bread to meet these needs. Sorghum (Sorghum bicolar L.) is nutritious, this study used a new sorghum genotype EUS130 in development of sorghum composite bread in the proportions wheat: sorghum flour 100:0 (Control), 96:4, 92;8, 88: and 84:16. Baking was done using Straight dough method. Nutrient content, shelf life, physical properties: height (dough strength), length (dough resistance to extensibility) and $\mathrm{W}$ (deformation energy), and baking properties: specific loaf volume, P/L ratio, loaf weight were determined. Sensory acceptability was done using $\mathbf{5 0}$ semi-trained panellists. The study observed that protein content was highest in $8 \%$ but decreased $\geq 12 \%$ sorghum, fat was higher in $\mathbf{8} \%$ sorghum bread compared to control. Dough height and $\mathrm{P} / \mathrm{L}$ ratio were highest in $8 \%$ sorghum while length was highest in control. At $16 \%$ sorghum, loaf texture, crumb colour, mouth feel and general appearance decreased. Microbial count was highest in wheat bread while shelf life increased with increase in sorghum. In conclusion, $8 \%$ sorghum flour can be partially substituted with wheat flour to develop bread with improved nutritional and sensory quality.
\end{abstract}

Keywords: Physical properties, shelf life, composite bread, nutritional quality, sensory quality.

\section{INTRODUCTION}

Refined wheat bread is one of the most commonly consumed item for breakfast and other meals but not affordable in developing countries that rely on wheat importation (Wambua et al. 2016). Wheat flour has been the main bread ingredient due to the functional protein gluten. In Kenya, bread consumption has increased however, increase in bread price from high importation has made bread unaffordable to many households (Sasson, 2012). Studies that explore the possibility of partly substituting wheat with locally grown crops have been done using sorghum (Sorghum bicolour) and millet

\section{Abbreviations}

SLV- Specific loaf volume

(Abdelghafor et al.2011), sweet potatoes (ljah et al.
2014), rice (Rai et al. 2012), maize and sorghum (Nkhubutlane et al. 2014). However, the newly produced sorghum genotype EUS130 and proportions below 5 have not been studied in the baking industry.

Wheat is a nutritious cereal, but the use of roller mill to produce refined wheat removes the bran and germ making the flour nutritionally inferior. More than $50 \%$ vitamins $B, E$ and nearly all fibre is lost in the bran (Heshe et al.2015). Whole grain has been associated with reduced risk of mortality from cardiovascular disease and some cancers (Aune et al.2016). Sorghum is a drought tolerant crop, it has a neutral smell and blends well with wheat (Adebowale et al. 2012; Ogeto et al. 2013). It contains 7-15\% protein (kafirins and prolamins), fatty acids mainly polyunsaturated fatty acids such as linoleic linolenic acid and oleic acid (Whelan and Fritsche 2013), fat soluble vitamins A, D, E and $K$ and water 
soluble vitamins such as riboflavin, pyridoxine and thiamine $2.3 \%-2.9 \%$ dietary fibre and Phytochemicals such as flavonols, flavones and minerals such as $\mathrm{Ca}, \mathrm{P}$, $\mathrm{K}, \mathrm{Fe}, \mathrm{Zn}, \mathrm{Mg}$ and $\mathrm{Cu}$ but tannin makes them unavailable for absorption (Afify et al.,2012).

Composite flour from whole sorghum flour helps to improve nutritional quality, utilize local crops, reduce cost of production as well as produce variety of products (Abdelghafor 2011). However, above 10\% wheat substitution with sorghum flour, acceptability rate is similar to the control but a darker crumb, lower specific loaf volume and bitter taste are observed hence acceptability declines. Sorghum composite confectionaries have been researched on in Kenya at high proportion but sorghum EUS130 has never been tried. Sorghum utilization in Kenya is still very low and this has continued to increase wheat importation; reduced market demand for sorghum while many Kenyan continue to die of under nutrition. Therefore, the objective of this study was to develop sorghum-wheat composite bread using small sorghum proportions so that the bread produced is almost similar to wheat bread. To achieve this objective, sorghum composite breads and wheat bread produced were compared for sensory acceptability; physical and baking properties, nutrient contents, in vitro protein digestibility and shelf life.

\section{MATERIALS AND METHODS}

\section{Site study}

A new red sorghum grain variety EUS130 (Sorghum bicolor) used in this study was obtained from Department of Horticulture Crops and Soil science Egerton University Kenya. Wheat flour (Pembe Bakers flour) was purchased from Pembe distributers' shop while other ingredients were obtained from shops in Nakuru town in large quantity for maintenance of quality. Laboratory analysis was done in Kenya Agricultural and Livestock Research Organization (KALRO) and Egerton University. Randomized Complete block design was adopted and the experimental treatments were wheat flour as the control and sorghum-wheat composite flours as the test variable. Samples were baked in triplicate grouped into 5 blocks so that treatments may be compared under homogenous condition.

\section{Preparation of sorghum flour}

Composite flour was prepared using a method described by Abdelghafor et al. (2013) with slight modifications. Sorghum grain was cleaned to remove foreign materials, dried (approximately 12\% moisture level) to remove moisture. Milling of sorghum was done using perten laboratory bench mill to produce fine whole meal flour above $80 \%$ extraction rate. Different blends of composite flour were prepared in the proportion bakers flour: sorghum flour 100:0 (control), 96:4, 92:8, 88:12 and $84: 16$. The composite flours were packaged into polyethylene bags to await use.

\section{Physical and baking properties of dough and bread}

The chopin- Alveograph machine (Tripetteet Renaud, France) was used to determine resistance to expansibility (height -strength) and Length (resistance to extensibility) and deformation energy $(\mathrm{W})$. The force $(\mathrm{W})$ required to inflate the dough until it ruptures was recorded on a graph and the ratio $P / L$ were determined.

\section{Experimental design}

Randomized complete block design was adopted in this study. Experimental treatments were wheat flour as the control and sorghum wheat composite flour, breads were baked in triplicate, grouped into 5 blocks so that treatments may be compared under homogenous condition. Data was analysed using SAS version 8, tables and figures are the average of triplicate observations, Differences between ranges of properties was determined using Least Significant difference (LSD) tests at $95 \%$ confidence level $(p<0.05)$

\section{Straight dough method for bread production}

Bread was prepared using straight dough method AACCI (1991) $11^{\text {th }}$ Edition with slight modification. Different blends made above were weighed to $100 \mathrm{~g}$ flour and mixed for 10 minutes using a manual blender. Other ingredients were added to the composite flour at different percentages of the weight of the bread as follows: $3 \%$ shortening/fat, $5 \%$ sugar, $3 \%$ milk powder, $1.5 \%$ instant yeast, $1 \%$ salt, $0.01 \%$ dobrin, $0.01 \%$ calcium propionate and the water used in dough making was determined using Brabendar Farinograph. Ingredients were mixed for 4 minutes using a dough mixer. The dough was rolled and put into fermentation cabinet at $30^{\circ} \mathrm{C} 85^{\circ} \mathrm{C}$ and relative humidity for 90 minutes. First punch was done by passing the dough through sheeter then folding it twice, placed back into the bowl and fermented for 50 minutes. Second punching was done and the dough was molded using hands, then shaped to fit the pre greased baking pan and allowed to proof for 55 minutes. Baking was done at $250{ }^{\circ} \mathrm{C}$ for $10-15$ minutes. Loaves were allowed to cool at room temperature and weighed for 2 hours and packed into polyethylene bags for 24 hours.

\section{Physical properties of sorghum composite bread}

Loaf volume was determined by rapeseed displacement method AACC (2000). Specific loaf volume (SLV) 
Table1. Physical and baking properties of wheat and sorghum-wheat composite dough and breads

\begin{tabular}{|c|c|c|c|c|c|c|}
\hline Sorghum \% & Loaf height (P-value) & Loaf length (L-value) & $\mathbf{P} / \mathbf{L}$ & Energy (J) & Specific loaf volume (SLV) & Loaf weight (g) \\
\hline 0 & $9.6 \pm 0.02^{0}$ & $10.8 \pm 0.02^{\mathrm{a}}$ & $0.90 \pm 0.003^{d}$ & $298.7 \pm 0.03^{b}$ & $5.7 \pm 0.11^{\mathrm{a}}$ & $140.2 \pm 0.87^{\mathrm{a}}$ \\
\hline 4 & $9.4 \pm 0.04^{c}$ & $8.8 \pm 0.04^{\mathrm{b}}$ & $1.2 \pm 0.001^{\mathrm{a}}$ & $289.9 \pm 0.05^{\mathrm{c}}$ & $3.8 \pm 0.05^{\mathrm{b}}$ & $142.6 \pm 0.40^{\mathrm{a}}$ \\
\hline 8 & $9.8 \pm 0.03^{a}$ & $7.37 \pm 0.20^{c}$ & $1.5 \pm 0.024^{\mathrm{a}}$ & $245.7 \pm 0.01{ }^{\mathrm{e}}$ & $3.7 \pm 0.15^{b}$ & $144.5 \pm 3.21^{\mathrm{a}}$ \\
\hline 12 & $9.7 \pm 0.02^{\mathrm{b}}$ & $6.5 \pm 0.02^{\mathrm{d}}$ & $1.3 \pm 0.023^{b}$ & $367.8 \pm 0.06^{\mathrm{a}}$ & $3.5 \pm 0.04^{b}$ & $142.2 \pm 0.16^{a}$ \\
\hline 16 & $7.5 \pm 0.02^{d}$ & $6.5 \pm 0.04^{d}$ & $1.25 \pm 0.003^{\mathrm{c}}$ & $277.3 \pm 0.03^{d}$ & $3.5 \pm 0.17^{\mathrm{b}}$ & $143.1 \pm 0.63^{\mathrm{a}}$ \\
\hline
\end{tabular}

Data are mean \pm standard deviations; values in a column with different superscript letters are significantly different, $p<0.05$ using analysis of variance (ANOVA) and least significant difference (LSD) for post doc analysis.Proportion wheat: sorghum- 0\%; 100:0 (control), 4\%; 96:4, 8\%; 92:8, 12\%; 88:12, 16\%; $84: 16$

calculated volume was determined by dividing loaf volume (cc) by weight (g) (volume/weight).

Bread was cut into $3 \times 4 \mathrm{~cm}$ pieces using a saw knife, three letter codes were used for labelling of the breads and presented 50 semi trained panellists for evaluation. A 9-point hedonic scale was used to rate the attributes (general appearance, loaf texture, crumb and crust colour cell size, flavour, smell, mouth feel) 1 representing extremely dislike and 9 for extremely like.

\section{Nutrient content}

Moisture content, crude, crude fibre, crude fat, ash and carbohydrate content were determined using AOAC (2000) method.

\section{In Vitro soluble protein digestibility}

In Vitro soluble protein digestibility was determined according to Akesson and Stahmann (1964) method, microbiological quality was determined by counting the total viable bacteria counts (coliforms and fungi) while shelf life was calculated by the number of days the bread remained fresh before mould was visible.

\section{Statistical Data analyses}

Data obtained from physical and baking properties, nutrient content and sensory analysis of sorghum composite bread was analysed by SAS Version 8 for analysis of variance (ANOVA) using General Linear Model (GLM) Means separation was done using Least Significant difference (LSD) method (Lynn et al., 2010) at $\mathrm{p}<0.05$.

\section{RESULT AND DISCUSSION}

Physical and baking properties of dough and breads

Physical dough characteristics of sorghum-wheat composite breads and control (wheat bread) (Table 1) shows that $8 \%$ sorghum-wheat composite bread had the highest $(p<0.05) P$-value $9.8 \pm 0.03$ compared to control bread $9.6 \pm 0.02$ while the $16 \%$ sorghum composite bread had the lowest. Dough length (L-value) was higher in control $10.8 \pm 0.02$ compared to $16 \%$ sorghum bread 6.5 \pm 0.04. Specific loaf volume was significantly high in wheat bread compared to sorghum composite samples. Deformation energy (W) value was highest $367.8 \pm 0.06(p<0.05)$ in $12 \%$ sorghum composite bread compared to control while energy SLV was highest in $12 \%$

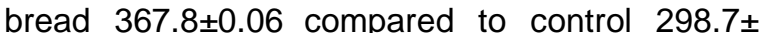
0.03 . Wheat bread had significantly $(p<0.05)$ high SLV 5.7 \pm 0.11 , values decreased with increase in sorghum level (Table 1).

The height ( $P$-value: resistance to elasticity), length (L-value resistance of the dough to expansion and extensibility) and configuration ratio $(\mathrm{P} / \mathrm{L})$ are presented in Table 1. It was evident that dough height and $P / L$ ratio had significantly high values in $8 \%$ sorghum while control had the highest resistance to extensibility (length). This variation in rheological properties may be attributed to dilution of protein gluten by nonwheat flour and high fibre which disrupts the continuous elastic network of the dough resulting to loss of gases. When adequate gases are trapped bread is less dense and of good quality (Kulamarva et al. 2009), SLV attained is high leading to desirable bread volume (Bakare et al., 2016). Bread with high L-value have low volume and less desirability (Gomez et al. 2003). In the study sorghum composite bread above $8 \%$ was 
116 Afr. J. Food Sci. Technol.

Table 2. Nutritional content of wheat and sorghum-wheat composite breads

\begin{tabular}{|c|c|c|c|c|c|c|c|c|}
\hline $\begin{array}{l}\text { Ratios } \\
\text { (wheat:sorghum) }\end{array}$ & Protein (g/100g) & Moisture $(\mathrm{g} / \mathbf{1 0 0 g})$ & Crude fat $(\mathrm{g} / \mathbf{1 0 0 g})$ & $\begin{array}{l}\text { Fibre } \\
(\mathrm{g} / 100 \mathrm{~g})\end{array}$ & Ash $(g / 100 g)$ & $\begin{array}{l}\text { Carbohydrate } \\
(\mathrm{g} / 100 \mathrm{~g})\end{array}$ & $\begin{array}{lc}\text { In } & \text { vitro } \\
\text { digestibility }\end{array}$ & protein \\
\hline Sorghum $0 \%(100: 0)$ & $10.21 \pm 0.49^{b}$ & $40.16 \pm 1.71^{\mathrm{a}}$ & $5.77 \pm 0.030^{C}$ & $3.08 \pm 0.70^{6}$ & $1.52 \pm 0.27^{\mathrm{a}}$ & $80.17 \pm 1.42^{\mathrm{a}}$ & $85.45 \pm 0.20^{a}$ & \\
\hline Sorghum $4 \%(96: 4)$ & $12.83 \pm 1.35^{\mathrm{ab}}$ & $40.70 \pm 0.80^{\mathrm{a}}$ & $5.83 \pm 0.12^{\mathrm{bc}}$ & $4.54 \pm 0.35^{a}$ & $1.53 \pm 0.09^{\mathrm{a}}$ & $75.57 \pm 0.75^{\mathrm{b}}$ & $85.42 \pm 0.24^{a b}$ & \\
\hline Sorghum $8 \%(92: 8)$ & $13.22 \pm 1.25^{\mathrm{a}}$ & $39.64 \pm 1.27^{a}$ & $6.57 \pm 0.28^{\mathrm{a}}$ & $4.44 \pm 0.89^{a}$ & $1.55 \pm 0.21^{\mathrm{a}}$ & $74.21 \pm 0.96^{\mathrm{b}}$ & $84.38 \pm 0.42^{\mathrm{ab}}$ & \\
\hline Sorghum $12 \%(88: 12)$ & $12.85 \pm 1.03^{\mathrm{ab}}$ & $39.36 \pm 1.67^{\mathrm{a}}$ & $6.12 \pm 0.04^{\mathrm{b}}$ & $4.78 \pm 0.88^{a}$ & $1.56 \pm 0.27^{\mathrm{a}}$ & $75.70 \pm 1.72^{\mathrm{b}}$ & $84.29 \pm 0.41^{\mathrm{ab}}$ & \\
\hline Sorghum $16 \%(84: 16)$ & $12.06 \pm 0.49^{\mathrm{ab}}$ & $36.87 \pm 1.69^{b}$ & $6.30 \pm 0.28^{a b}$ & $4.27 \pm 0.70^{\mathrm{a}}$ & $1.86 \pm 0.21^{\mathrm{a}}$ & $75.51 \pm 0.66^{b}$ & $84.13 \pm 0.37^{\mathrm{ab}}$ & \\
\hline Wheat flour & $13.81 \pm 0.49$ & $12.82 \pm 3.45$ & $5.73 \pm 0.68$ & $3.2 \pm 0.72$ & $1.52 \pm 0.46$ & $75.74 \pm 0.35$ & & \\
\hline Sorghum flour & $13.23 \pm 0.63$ & $12.99 \pm 7.45$ & $3.55 \pm 0.23$ & $6.49 \pm 7.31$ & $1.55 \pm 0.36$ & $75.19 \pm 9.27$ & & \\
\hline
\end{tabular}

Data are means \pm standard deviations; values in a column with different superscript letters are significantly different, $p<0.05$ using analysis of variance (ANOVA) and least significant difference (LSD) for post doc analysis. Proportion wheat: sorghum- $0 \% ; 100: 0,4 \% ; 96: 4,8 \% ; 92: 8,12 \% ; 88: 12,16 \% ; 84: 16$

heavier, more soft, less spring, and crumbly during slicing compared to wheat bread. The study is in agreement with Bakare et al. (2016); Sibanda et al. 2015) who observed at $10 \%$ composite dough, L-value and P-value were higher in wheat flour dough compared to composite dough. In the study, dobrin was used to help improve dough strength, enhanced dough tolerance and bread quality as used in baking industry.

\section{The nutrient content}

Protein content was higher $13.22 \pm 1.25$ $(p<0.05)$ in $8 \%$ sorghum compared to $10.21 \pm 0.49$ in wheat bread, values decreased at $12 \%$ sorghum. Moisture lowest in $16 \%$ sorghum bread, crude fat was high $(p<0.05)$ in $8 \%$ sorghum composite bread $6.57 \pm 0.28 \mathrm{~g} / 100 \mathrm{~g}$ compared to control $5.77 \pm 0.030 \mathrm{~g} / 100 \mathrm{~g}$. Fibre content in $8 \%$ sorghum bread $4.44 \pm 0.89 \mathrm{~g} / 100 \mathrm{~g}$ was higher compared to control $3.08 \pm 0.70 \mathrm{~g} / 100 \mathrm{~g}$. Furthermore, the ash level was higher in $8 \%$ sorghum bread $(1.55 \pm 0.21 \mathrm{~g} / 100 \mathrm{~g})$ compared to $1.52 \pm 0.27 \mathrm{~g} / 100 \mathrm{~g}$ control. However, the carbohydrate content was lower in $8 \%$ composite bread $74.21 \pm 0.96 \mathrm{~g} / 100 \mathrm{~g}$ compared to control $80.17 \pm 1.42 \mathrm{~g} / 100 \mathrm{~g}$ (Table 2). This study found out that the protein content in $8 \%$ sorghum-wheat composite breads was higher than in wheat bread (Table 2) however, as the sorghum level increased to $12 \%$, the protein level decreased possibly due to high carbohydrate levels and variation in chemical composition of wheat gluten.. Higher protein content was also observed in sorghum-millet composite cookies (Rai et al, 2014). Previous studies associated low protein in sorghum kernel to low protein in sorghum bread (Sibanda et al., 2015) and in cassava composite bread (Wambua et al.2016). The recommended protein intake is $0.8 \mathrm{~g} / \mathrm{kg} /$ day which sufficient to meet the needs of nearly $97.5 \%$ of healthy persons of 19 years and above (Campbell et al. 2007). Thus, consumption of 2 slices of bread for breakfast $(56 \mathrm{~g})$, would meet 10.18 to 13.93 , recommended dietary intake protein per day in the 0 to $16 \%$ sorghum composite bread. Low carbohydrate level in sorghum composite breads than in wheat bread might be due to lower carbohydrate level in sorghum flour.

Similar trend was obtained by Adebowale et al. (2012) and concurs with a recent study (Serrem et al.2015) in composite biscuits. Moisture content reduced with increased sorghum level which may be attributed to high 

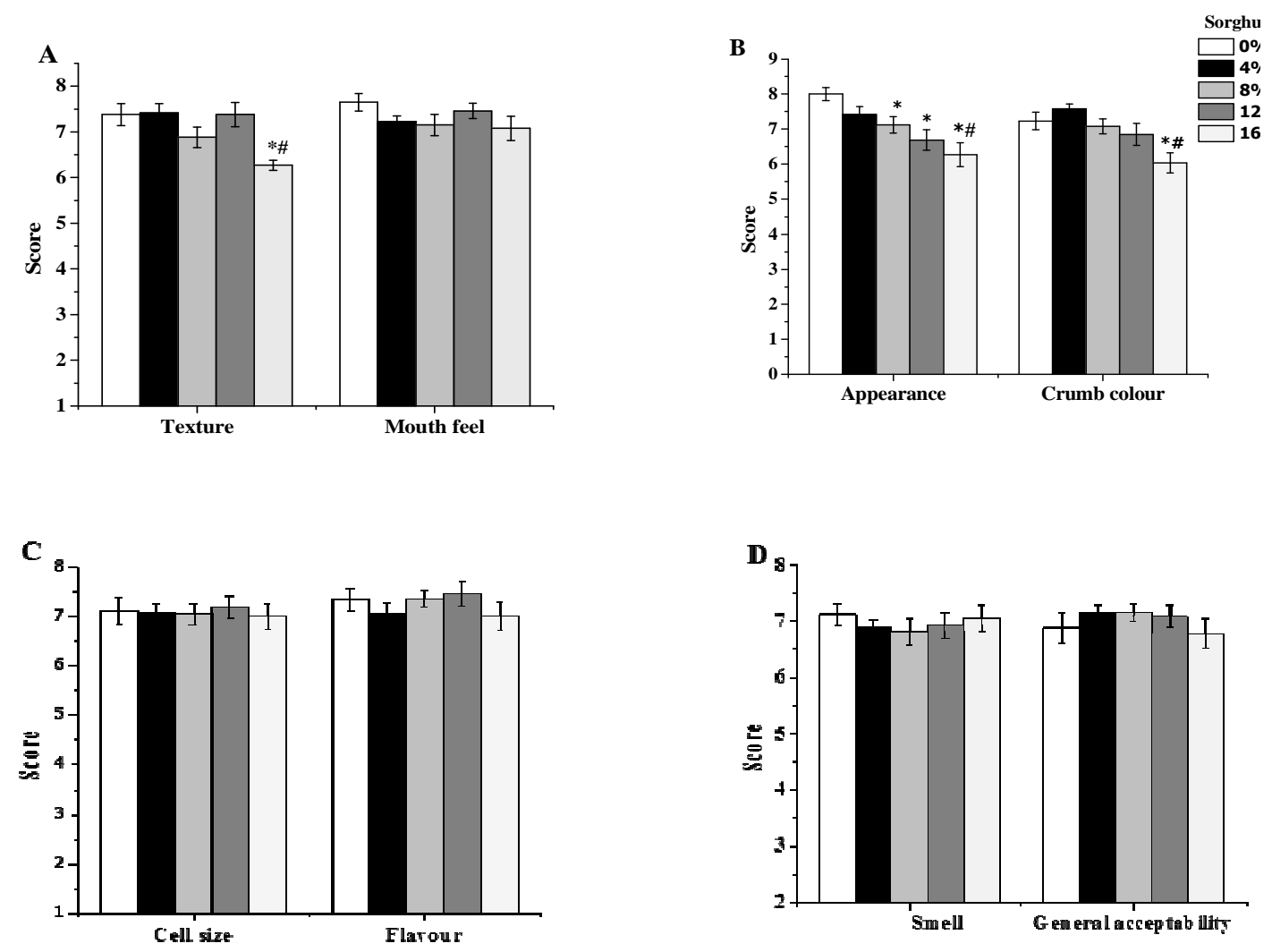

Figure 1. Sensory properties of wheat and sorghum-wheat composite breads. Data are means \pm standard deviations of scores from 9-point hedonic scale, 9- extremely like; 8-like very much; 7-like moderately; 6-like slightly; 5-neither like nor dislike; 4-dislike slightly; 3-dislike moderately; 2-dislike very much; 1-dislike extremely. " $\mathrm{p}<0.05$ compared with control; Texture- "P<compared to $4 \%$ and $12 \%$ sorghum bread; Appearance- ${ }^{\#} \mathrm{p}<\mathrm{compared}$ with $4 \%$ bread; crumb colour- ${ }^{p} \mathrm{p}<0.05$ compared with $4 \%, 8 \%, 12 \%$ sorghum bread using analysis of variance (ANOVA) and least significant difference (LSD) for post hoc analysis

moisture loss during and after baking and the high hydrophobic characteristic of sorghum protein; an advantage in reduction of microbial proliferation thus prolonging storage period of products (Sanni et al.2006). There was a remarkable decrease in crude fat values as sorghum level increased beyond $8 \%$. This may have been due to binding by dietary fibre or low moisture content which lowers sorghum fat extraction by hindering heat transfer between solids and solvents during extraction (Wang et al.2005). The ash in composite sorghum breads increased with increase in sorghum flour, high ash confirms that bread can be used to deliver essential micronutrients to populations for reduction of micronutrient deficiency.

\section{In vitro protein digestibility}

In vitro protein digestibility was high $(85.45 \pm 0.20)$ in control and lowest $(84.08 \pm 0.50)$ in $16 \%$ sorghum bread (Table 2). Studies (Latimer and Haud, 2010) observed that dietary fibre binds nutrients resulting to indigestion in small intestines an advantage in diabetic persons.

\section{Sensory evaluation of the breads}

The texture score values up to $12 \%$ sorghum (Figure. 1A) and general appearance (Figure. IB) were similar with control. Mouth feel scores for sorghum composite loaves of bread were similar to control (Figure. 1A). Cell size, loaf flavour (Figure. 1C) while smell/aroma and general acceptability scores (Figure. 1D) for sorghum bread were similar to wheat bread. The neutral smell and taste of EUS130 sorghum flour may contributed to composite bread sensory acceptability. Crumb colour was lowest in $16 \%$ sorghum bread due to a darker colour unfamiliar colour by panellists may have resulted to reduced desirability and likeability decreased. Consumers often prefer a lighter bread colour which is associated with raw materials used for wheat bread Abdelghafor et al., (2011).

\section{Microbiological quality}

Total viable counts (cfu/g) were significantly low in $12 \%$ sorghum composite bread compared to wheat bread 
118 Afr. J. Food Sci. Technol.

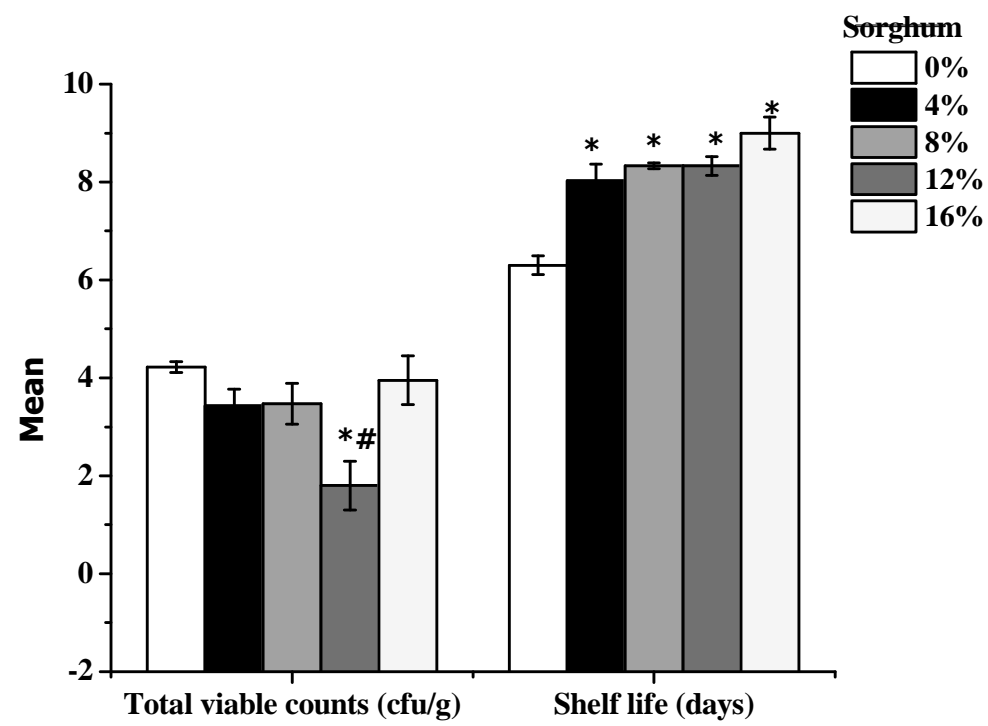

Figure 2. Total viable counts (cfu/g) and shelf life (days) of wheat and sorghumwheat composite breads. ${ }^{*} p<0.05$ compared with control bread (wheat); $\# p<0.05$ compared with $4 \%, 8 \%$ and $12 \%$ bread using analysis of variance (ANOVA) and LSD for post hoc analysis

which may have been due handling during baking process and low moisture. Composite bread had longer shelf life (days) * $p<0.05$ compared with control bread (Figure. 2). In the study, fungi were not present in all the bread samples implying that the breads were safe for human consumption. The lowest level of cfu/g found in $12 \%$ sorghum was possibly due to handling of bread samples.

\section{CONCLUSIONS}

The study demonstrated that the $8 \%$ sorghum-wheat composite bread had higher protein, crude fat and fibre content as compared to wheat bread. Shelf life increased with increase in proportion of sorghum in composite bread and this was reflected by low microbial counts detected; an advantage in rural area where storage facilities are a challenge. Therefore, partial substitution of wheat with $8 \%$ whole sorghum flour can produce acceptable and nutritious bread with comparable long shelf life.

\section{ACKNOWLEDGEMENT}

This research work was supported by Kenya Agricultural productivity programme (KAPP). We thank the staff of Kenya Agricultural and Livestock Organization (KALRO) cereal chemistry laboratory and Animal science laboratory for assisting in lab work. We appreciate
Ancetta Gakii and Samwel Kariithi for assisting in data analysis.

\section{REFERENCES}

AOAC (2000). Official Methods of Food Analysis Association of Official Analytical Chemists, St. paul Washington.

Abdelghafor AI, Mustafa AM, Ibrahim MH, Krishnan PG (2011). Quality of bread from sorghum composite flour and hard white winter wheat. J. food sci. and technology 1:9-15.

Abdelghafor R, Mustafa A, Ibrahim A, Chen Y, Krishnan P (2013). Effects of sorghum flour addition on chemical and rheological properties of hard white winter wheat. J. Food Sci. Technology 5: 1407-1412.

Abdualrahman MY, Ma H, Yagoub GA, Zhou C, Ali OA, Yang W (2016).Nutritional value, protein quality and antibiotic activity of Sudanese sorghum based kisra bread fortified.J. Sci. Doi. 10.1016/j.jssas.2016.12.003.

Adebowale AA, Adegoke MT, Sanni SA, Adegonwa MO, Fetuga GO (2012).Functional properties and biscuit making potential of sorghum- wheat flour composite. Ame. J. Food Technology 7: 372379.

Afify AM, El-Beltagi HS, Abdi, S.M, and Omran, AA (2012). Protein solubility, digestibility and fractionational after germination of sorghum varieties. J. botany horticulture and agronomy 2:40:1-7.

Akenson WR, Stahmann MA (1964). A pepsin pancreatin digest index of protein quality evaluation. J. Nutr. 83(1964): 257-261.

AACCI (1991). Approved Methods of Analysis 11th Ed. Method 1009.01. Basic straight dough bread baking method-long fermentation. Approved November $3^{\text {rd }}$. AACC International, St. Paul, MN.

Bakare H.A, Osundahunsi FO. Olusanya J (2016). Rheological, baking, and sensory properties of composite bread dough with breadfruit (Artocarpus communis Forst) and wheat flours. J. Food Sci. and Nutri. 4: 573-587.

Campbell B, Kreidel BR, Ziegenfu T, Bounty PL, Roberto M, Burke T, Landies T, Lopez H, Antonio J (2007). International society of sports nutrition position stand: Protein and exercise. J. the International society sports nutrition 2007(4):8 doi10.1186/1550-2783-4-8. 
Gómez M, Ronda F, Blanco, C.A, Caballero, P.A, Apesteguia A (2003). Effect of dietary fibre on dough rheology and bread quality. European j. Food Res. and Technol. 216:51-56.

Latimar JM. Haud MD (2010). Effect of dietary fibre and its components on metabolic health. International j. food properties 2(12): 12661289.

Nkhubutlane PR, Ge-Kock HL (2014). Quality characterization of wheat maize and sorghum: steamed Lesotho bread from Lesotho. Intl. j. sci. in food and Agriculture 94: 1-7.

Ogeto RM, Cheruiyot E, Mshenga P, Onyari CN (2013). Sorghum production for food security: A socio-economic analysis of sorghum production in Nakuru County, Kenya. African J. Agric.Res. 8: 60556067.

Quality of flash and rotary dried fufu flour. J. Food Agric. Environ. 4: 7478.

Rai S, Kaur A, Singh B (2012). Quality characteristics of bread produced from wheat, rice and maize flours. Food Science Technology 49: 786-789.a

Sanni OL, Adebeowale AA, Filani TA, Oyewole OB, Westby A (2006).

Serrem AC, De Kock, HL, Taylor RN (2015). Nutritional quality, sensory quality and consumer acceptability of sorghum bread and wheat biscuits fortified with defatted soy. Intl. j. food sci. and technol. 1:4-15

Sibanda S, Ncube T, Ngoromane N (2015). Rheological properties and bread making quality of white grain sorghum- wheat flour composites. Intl. j. food science nutrition Engineering 5: 176-182.
Wambua M, Matofari J, Faraj A, Lamuka O (2016). Effect of different cassava varieties (manihotestculenta) and substitution levels in baking of wheat-cassava composite bread onphysical properties and sensory characteristics. African j. food sci. technol. 7(6): 131139.

Wang L, Weller CL, Hwang KP (2005). Extraction of lipid from grain sorghum. DDG.J. biological systems engineering 48(5):1883-1888

Whelan, Fristsche K (2013). Linoleic acid. American society journal for advance Nutrition 4,311:3120 (downloaded information from advances. Nutrition Org.at Kenya: ASNA on August 24 $4^{\text {th }}, 2016$ )

Williams J, Abdi H (2010). Fisher's Least Significant Difference Test In Neil Salkind (Ed), Encyclopedia of Research Design. Thousand Oaks, CA: Sage. 2010 